\title{
Effect of seed polymer coating with micronutrients and foliar spray on seed quality parameters of resultant seed in chickpea (Cicer arietinum $\mathbf{L}$.)
}

\author{
Pavan Shinde $^{1}$, S. R. Doddagoudar ${ }^{2 *}$ and S. N. Vasudevan ${ }^{2}$ \\ ${ }^{1}$ Department of Seed Science and Technology, University of Agricultural Sciences, Dharwad-580005, INDIA \\ ${ }^{2}$ Department of Seed Science and Technology, University of Agricultural Sciences, Raichur -584104 (Karnataka), INDIA \\ *Corresponding author. E-mail:srdsst@gmail.com
}

Received: December 27, 2015; Revised received: June 03, 2016; Accepted: August 21, 2016

\begin{abstract}
A laboratory experiment was carried out in the Department of Seed Science and Technology, College of Agriculture, University of Agricultural Sciences, Raichur to study the effect of seed polymer coating with micronutrients and foliar spray on the resultant seed quality parameters of chickpea. Among the seventeen different treatments, resultant chickpea seeds obtained from treatment polymer coated seeds (each@6 ml/kg of seed) along with the combination of micronutrients viz., $\mathrm{ZnSO}_{4}+$ Boron + Ammonium molybdate $+\mathrm{FeSO}_{4}$ ( each @ $2 \mathrm{~g} / \mathrm{kg}$ of seed ) and two foliar sprays $\left(0.5 \%+0.2 \%+0.1 \%+0.5 \%\right.$, respectively, except $\mathrm{ZnSO}_{4}$ and $\mathrm{FeSO}_{4}$ in EDTA form $)$ at an interval of 10 days during flowering stage (50 and 60 days after sowing) recorded significantly highest hundred seed weight $(25.9 \mathrm{~g})$, germination $(97.00 \%)$, speed of germination $(18.50)$, shoot length $(8.43 \mathrm{~cm})$, root length $(19.80 \mathrm{~cm})$, seedling dry weight $(43.30 \mathrm{mg})$ and seedling vigour index (2738) compared to all other treatments and control (23.6 $\mathrm{g}, 92.05 \%, 13.74,5.48 \mathrm{~cm}, 16.30 \mathrm{~cm}, 34.00 \mathrm{mg}$ and 2004, respectively) and hence above treatment combinations can be used in order to produce good quality seeds.
\end{abstract}

Keywords: Chickpea, Micronutrients, Polymer coating, Seed quality parameters

INTRODUCTION

Among the pulses, chickpea (Cicer arietinum L.) is a major crop, which is highly nutritious grain legume and one of the cheapest sources of energy and protein. But, the slow growth in pulse production compared to enormous increase in human population led to the progressive decline in the per capita availability of pulses. (Anonumous, 2010). In India, chickpea is grown in an area of 10.22 million hectares with a production of 9.88 million tonnes and an average productivity of 967 $\mathrm{kg}$ per hectare (Anon., 2014) which is far less to the world average productivity. In order to improve the productivity, it is necessary to supply the good quality seed to the farmers, as it is a proven fact that the productivity of many crops can be increased by $20-25$ percent by mear use of high quality seed.

For optimum growth and development of crop plants, 17 elements are very much essential. These minerals, when required in relatively high amounts are called macronutrients or in trace amounts, micronutrients. Since, micronutrients are required in relatively smaller quantities for plant growth, they are as important as macronutrients (Farooq et al.,2012). They often act as co-factors in enzyme systems and participate in redox reactions and having several other vital functions in plants (Mengel et al., 2001). Among the micronutrients, zinc, boron, ferrous sulphate and ammonium molybdate are very important for pulses as zinc is in- volved in biosynthesis of plant hormone and is a component of variety of enzymes like, carbonic anhydrase, alcohol dehydrogenase, glutamic dehydrogenase. It also plays an important role in nucleic acid and protein synthesis and helps in utilization of phosphorus and nitrogen in seed formation and development. Ferrous sulphate is another important micronutrient which is a constituent of chlorophyll biosynthesis, regulates respiration, photosynthesis, reduction of nitrates and sulphates and also activates several enzymes involved in respiration (Kaleeswari et al., 2013). While, boron plays an important role in flower retention, pollen tube growth, seed formation and seed setting and mainly involved in translocation of metabolites from source to sink (Tanaka and Fujiwar, 2008). While, molybdenum involved in nitrogen assimilation and helps root nodule bacteria to fix atmospheric nitrogen (Campo et al., 2000).

These micronutrients may be supplied to the plants through soil application, foliar spray or seed treatment. Micronutrient application through seed treatments improves the stand establishment, advances phonological events and increases yield and micronutrient grain contents in many crops (Farooq et al, 2012). In many cases, micronutrient application through seed treatment performed better or similar to other application methods (Singh et al., 2003). Being an easy and cost effective method, seed treatment by polymer coating along with foliar spray offer an attractive option for resource 
poor farmers through its pronounced effect during the early stage of seedling establishment (Johnson et al., 2005) and seedling growth (Singh et al., 2003). Keeping in view the above facts, the present investigation was carried with an objective to study the influence of seed coating with micronutrients and foliar spray on seed quality of the resultant seed of chickpea.

\section{MATERIALS AND METHODS}

An experiment was conducted in the Department of Seed Science and Technology, College of Agriculture, University of Agricultural Sciences, Raichur during the year 2014 to study the effect of seed polymer coating with micronutrients and foliar spray on seed quality parameters of the resultant seed of chickpea cultivar JG-11. The experiment consisted of seventeen different treatments which were imposed with different micronutrients either individually or in combination along with polymer ( Disco Agro DC Red L-603 procured from Incotec Pvt. Ltd. Ahmedabad, Gujarat) @ 6 $\mathrm{ml}$ per $\mathrm{kg}$ of seed dissolved in $45 \mathrm{ml}$ water in a rotary seed coating machine except control viz., $\mathrm{T}_{1}: \mathrm{ZnSO}_{4} @$ $2 \mathrm{~g}$ per kg of seed, $\mathrm{T}_{2}: \mathrm{ZnSO}_{4} @ 4 \mathrm{~g}$ per kg of seed, $\mathrm{T}_{3}$ : Boron@2 g per kg of seed, $\mathrm{T}_{4}$ : Boron@ $4 \mathrm{~g}$ per kg of seed, $\mathrm{T}_{5}$ : Ammonium molybdate @ $2 \mathrm{~g}$ per kg of seed, $\mathrm{T}_{6}$ : Ammonium molybdate @ $4 \mathrm{~g}$ per kg of seed, $\mathrm{T}_{7}$ : $\mathrm{FeSO}_{4} @ 2 \mathrm{~g}$ per kg of seed, $\mathrm{T}_{8}: \mathrm{FeSO}_{4} @ 4 \mathrm{~g}$ per kg of seed, $\mathrm{T}_{9}: \mathrm{T}_{1}+\mathrm{T}_{3}, \mathrm{~T}_{10}: \mathrm{T}_{1}+\mathrm{T}_{5}, \mathrm{~T}_{11}: \mathrm{T}_{1}+\mathrm{T}_{7}, \mathrm{~T}_{12}: \mathrm{T}_{3}$ $+\mathrm{T}_{5}, \mathrm{~T}_{13}: \mathrm{T}_{3}+\mathrm{T}_{7}, \mathrm{~T}_{14}: \mathrm{T}_{5}+\mathrm{T}_{7}, \mathrm{~T}_{15}: \mathrm{T}_{1}+\mathrm{T}_{3}+\mathrm{T}_{5}+\mathrm{T}_{7}$, $\mathrm{T}_{16}$ : Only polymer, $\mathrm{T}_{17}$ : Absolute control.The coated seeds were properly dried in shade to bring back their original moisture content and sown in the field following standard agronomic practices in a randomised bock design. During flowering stage (50 and 60 DAS) two foliar sprays at an interval of 10 days were given either individually or in combination as per the treatments (ZnSO $40.5 \%+$ + Boron@0.2\%+Ammonium molybdate@0.1\%+ $\mathrm{FeSO}_{4} @ 0.5 \%$, respectively, $\mathrm{ZnSO}_{4}$ and $\mathrm{FeSO}_{4}$ in EDTA form). At physiological maturity the seeds were harvested followed by proper threshing and drying and subjected for assessing various seed quality parameters viz., seed germination percentage was worked out by putting 100 seeds each in four replications by following between paper method and the rolled towels were incubated in the walk in seed germinator maintained at 25 degree celcius with 90 percent relative humidity (ISTA, 1999), speed of germination was worked out (Maguire, 1962) by counting the number of seeds that geminated on daily basis up to the day of final count, shoot length, root length, seedling dry weight and vigour index was calculated as per the formula suggested (Abdul-Baki and Anderson, 1973). The data of the laboratory experiment were statistically analyzed by adopting completely randomized design as outlined by Sundararaj et al. (1972). The critical difference were calculated at one per cent level of probability, Wherever ' $F$ ' test was found significant for various seed quality parameter under study.

\section{RESULTS AND DISCUSSION}

The results obtained on various resultant seed quality parameters of chickpea obtained from seed polymer coated with micronutrients and foliar sprays after their harvest from the field are presented below:

100 seed weight (g): In the present study, significantly higher hundred seed weight (25.9 g) was recorded by the seed harvested from $\mathrm{T}_{15}$ treatment (seed polymer coating with $6 \mathrm{ml} / \mathrm{kg}$ along with combination of micronutrients namely, $\mathrm{ZnSO}_{4}+$ Boron + Ammonium molybdate $+\mathrm{FeSO}_{4}$ each at $2 \mathrm{~g}$ per $\mathrm{kg}$ of seed ) along with two foliar sprays $(0.5 \%+0.2 \%+0.1 \%+0.5 \%$, respectively, except $\mathrm{ZnSO}_{4}$ and $\mathrm{FeSO}_{4}$ in EDTA form) at an interval of 10 days during flowering stage (50 and 60 DAS) ) compared to all other treatments and control (23.6 g) (Table 1). This increase in hundred seed weight might be due to better seed filling as the micronutrients play an important role in pollen germination, seed development, cell division, translocation of sugar and starch from source to sink (Masuthi et al., 2009). Similar results were reported by Umarani et al. (2003) in black gram by seed pelleting with DAP (40 g) + $\mathrm{ZnSO}_{4}(100 \mathrm{mg})+\mathrm{FeSO}_{4}(100 \mathrm{mg})+$ ammonium molybdate $(250 \mathrm{mg})$ using 10 per cent maida as an adhesive and Dixit and Elamathi (2007) in green gram due to foliar application of DAP $(2 \%)+$ Napthelene acetic acid $(40 \mathrm{ppm})+\mathrm{B}(0.2 \%)+\mathrm{Mo}(0.05 \%)$.

Seed germination $(\%)$ : The seed germination $(97.00$ $\%$ ) was significantly higher in the seeds harvested from $\mathrm{T}_{15}$ treatment compared to all other treatments and control (92.05\%) (Table 1) as it had supplied the required micronutrients for better seed development which in turn might have influenced the seed germination. Similarly, Harris et al., (2008) demonstrated that the chick pea seed Zinc content was increased by 29 per cent through seed priming with Zinc sulphate over the control. Priming seeds in $\mathrm{Zn}$ solution increased grain $\mathrm{Zn}$ contents in , chickpea, lentil, rice and wheat (Johnson et al., 2005). This is in turn dependent on the efficient synthesis, accumulation of food metabolites such as protein, carbohydrates and their translocation from source to the developing seed (sink) at greater ease (Shkolnik and Abdurashitov, 1958). Seed priming with $\mathrm{Zn}$ improved germination and seedling development in barely (Ajouri et al., 2004). Similarly, Ozturk et al. (2006) studied the effect of foliar $\mathrm{Zn}$ application on the concentration of $\mathrm{Zn}$ in seeds of a bread wheat cultivar and found that after 36 hours of germination, the coleoptile and roots that emerged showed very intensive red colour formation and had $\mathrm{Zn}$ concentration up to $200 \mathrm{mg} / \mathrm{kg}$ indicating substantial remobilization of $\mathrm{Zn}$ from seed pools into the developing roots (radical) and coleoptile thus highlighting the involvement of $\mathrm{Zn}$ in physiological processes during early 
Pavan Shinde et al. / J. Appl. \& Nat. Sci. 8 (3): 1623 - 1628 (2016)

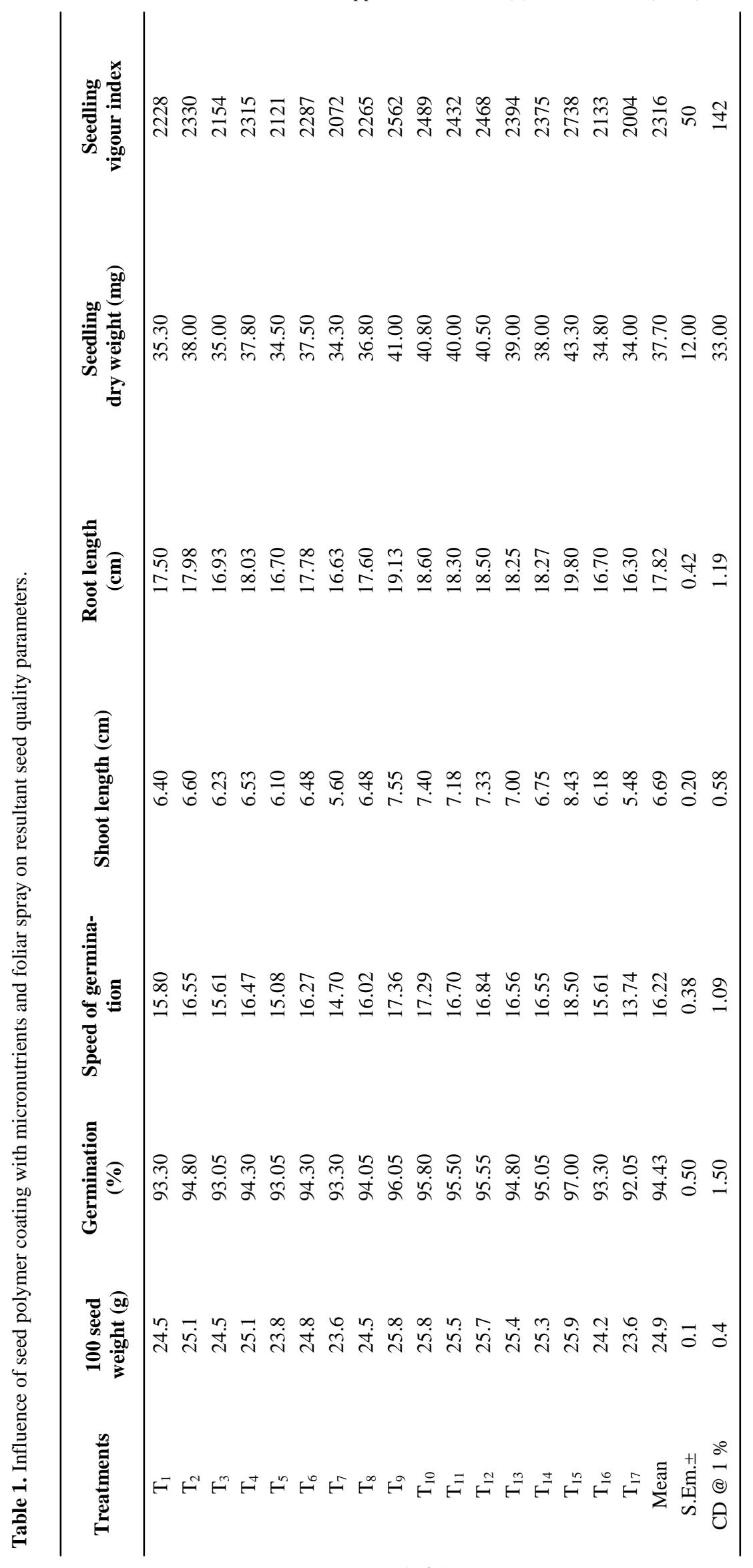




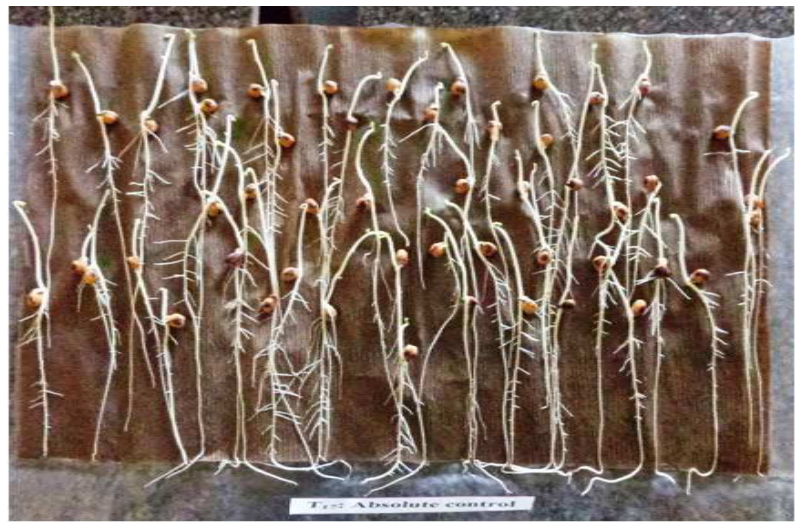

Control $\left(T_{17}\right)$

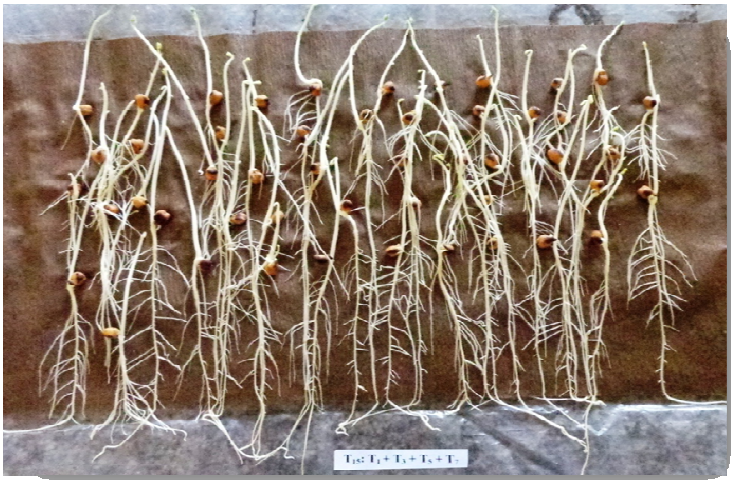

Micronutrient treatment $\left(T_{15}\right)$

Plate 1. Influence of micronutrients on seedling vigour of the resultant seed in chickpea.

seedling development, possibly in protein synthesis, cell elongation membrane function and resistance to abiotic stresses (Cakmak, 2000). In addition, higher seed $\mathrm{Zn}$ contents may better resist invasion of soilborne pathogens during germination and seedling development thus ensuring good crop stand (Marschner, 1995). Kaur et al. (2009) also reported improved germination of Chlorophytum borivilianum (L.) from seeds soaked in $\mathrm{Zn}\left(\mathrm{ZnSO}_{4}\right)$ for $12 \mathrm{~h}$. Substantial improvement in germination and early seedling growth was observed when seeds of papaya were primed in 2 mg per litre B solution for $6 \mathrm{~h}$ (Deb et al., 2010). However, Rahman et al., (2014) did not find any significant variation in seed germination due to seed treatment with boron ( $2 \mathrm{~g} / \mathrm{kg}$ of seed) and molybdenum (1 g/kg seed) in chickpea.

Speed of germination:Among the treatments, significantly higher speed of germination (18.50) was recorded by $\mathrm{T}_{15}$ compared to all other treatments and control (13.74) (Table 1). This could be due to the activation of cells, which might have resulted in the enhancement of mitochondrial activity leading to the formation of high energy compounds and vital biomolecules, which were made available during early phase of germination (Dharmalingam et al., 1998) and also due to nitrogen containing compound that might have stimulated the speed of germination with the increase in the seed cytokine content, which interact with growth inhibitors and enhance metabolic process leading to higher speed of germination. Similarly, Kavitha (2002) also reported that, seed with higher initial capital food reserve (test weight) always showed rapid and faster germination.

Shoot and root length $(\mathbf{c m})$ :Similarly, significantly higher shoot and root length $(8.43 \mathrm{~cm}$ and $19.80 \mathrm{~cm}$, respectively) were recorded from the seeds that were harvested from $\mathrm{T}_{15}$ treatment compared to all other treatments and control $(5.48 \mathrm{~cm}$ and $16.30 \mathrm{~cm}$, respectively) (Table 1). This might be due to increased meta- bolic activity of indole acetic acid and auxin (Krishnasamy, 2003) through the micronutrients and its translocation leading to faster cell division and elongation leading to increase in root and shoot length. Similar results were also reported by Srimathi et al. (2007) in green gram due to hardening with $\mathrm{MnSO}_{4}$ (100 ppm) and prosopis leaf extract $(1 \%)+$ pelleting with DAP $(40 \mathrm{~g})+\mathrm{MnSO}_{4}(100 \mathrm{mg})+\mathrm{FeSO}_{4}(100$ $\mathrm{mg})+$ ammonium molybdate $(250 \mathrm{mg})$ per $\mathrm{kg}$ of seed and Harish Babu et al., (2005) by pelleting green gram seeds with micronutrient mixture $(2 \%$ iron $+1 \%$ manganese $+3 \%$ zinc $+0.5 \%$ boron) .

Seedling dry weight (mg) and seedling vigour index: Among the different treatments, significantly higher seedling dry weight $(43.3 \mathrm{mg}$ ) was recorded by $\mathrm{T}_{15}$ as compared to all other treatments and control (34.0 mg). This could be due to better seedling length (root + shoot) as well as enhanced lipid utilization through glyoxylate cycle, a primitive pathway leading to faster growth and development of seedling to reach autotrophic stage well in advance of others and enabling them to produce relatively more quantity of dry matter (Jayaraj, 1997) and finally resulted in significantly higher seedling vigour index (2738) compared to other treatments (Table 1 and Plate 1) and untreated control (2004). Similar results were reported by Harish Babu et al., (2005) by pelleting green gram seeds with micronutrient mixture $(2 \% \mathrm{Fe}+1 \% \mathrm{Mn}+3 \% \mathrm{Zn}+$ $0.5 \% \mathrm{~B}$ ) and Srimathi et al. (2007) by hardening green gram seeds with $\mathrm{MnSO}_{4}(100 \mathrm{ppm})$ and prosopis leaf extract $(1 \%)+$ pelleting with DAP $(40 \mathrm{~g})+\mathrm{MnSO}_{4}$ $(100 \mathrm{mg})+\mathrm{FeSO}_{4}(100 \mathrm{mg})+$ ammonium molybdate (250 mg) per kg seeds, Kavitha (2002) in blackgram seeds hardened with prosopis leaf extract $(1 \%)$ followed by pelleting with $40 \mathrm{~g}$ DAP $+100 \mathrm{mg} \mathrm{ZnSO}_{4}+$ $100 \mathrm{mg} \mathrm{FeSO}+250 \mathrm{mg}$ ammonium molybdate per kg of seed. Similarly, Deepika and Pitagi (2015) reported higher seedling dry weight $(5.07 \mathrm{mg})$ of the resultant seed with the combination of $\mathrm{RDF}+\mathrm{ZnSO}_{4} @ 10 \mathrm{~kg}$ 
per ha+Borax @ 0.1\% spray at bud initiation stage in radish. However, Rahman et al., (2014) did not find any significant variation in seedling dry weight and vigour index due to seed treatment with boron $(2 \mathrm{~g} / \mathrm{kg}$ seed) and molybdenum ( $1 \mathrm{~g} / \mathrm{kg}$ seed $)$ in chickpea.

\section{Conclusion}

Polymer coating (@6 ml/kg) of chickpea seeds along with $\mathrm{ZnSO}_{4}+$ Boron + Ammonium molybdate + $\mathrm{FeSO}_{4}$ (each @ $2 \mathrm{~g} / \mathrm{kg}$ of seeds) with two foliar sprays $(0.5 \%+0.2 \%+0.1 \%+0.5 \%$, respectively, except $\mathrm{ZnSO}_{4}$ and $\mathrm{FeSO}_{4}$ in EDTA form) at an interval of 10 days during flowering stage (50 and 60 days after sowing ) resulted in significant increase in hundred seed weight $(25.9 \mathrm{~g})$, germination $(97.00 \%)$, speed of germination (18.50), shoot length $(8.43 \mathrm{~cm})$, root length $(19.80 \mathrm{~cm})$, seedling dry weight $(43.30 \mathrm{mg})$ and seedling vigour index (2738) compared to other treatments and control $(23.6 \mathrm{~g}, 92.05 \%, 13.74,5.48 \mathrm{~cm}$, $16.30 \mathrm{~cm}, 34.00 \mathrm{mg}$ and 2004, respectively). Hence, the seed producing organizations can use this technology for suppling the micronutirnets to the seed during early seed germination which helps in better germination with high vigour.

\section{ACKNOWLEDGEMENTS}

The authors wish to sincerely acknowledge Rashtriya Krishi Vikas Yojana (RKVY) Government of Karnataka, India and University of Agricultural Sciences, Raichur for the financial support.

\section{REFERENCES}

Abdul-Baki, A. A. and Anderson, J. D. (1973). Vigour determination in soybean seeds by multiple criteria. Crop Sci., 13 : 630-633.

Ajouri, A., Asgedom, H. and Becker, M. (2004). Seed priming enhances germination and seedling growth of barley under conditions of $\mathrm{P}$ and $\mathrm{Zn}$ deficiency. J. Plant Nutr. Soil Sci., 167 : 630-636.

Anonymous, 2010, www.icmr.nic.in

Anonymous. (2014). Agriculture at glance: Directorate of Economics and statistics, Department of Agriculture and Cooperation. pp. 94-96.

Cakmak, I. (2000). Role of zinc in protecting plant cells from reactive oxygen species. New Phytol., 146 : 185-205.

Campo, R. J., Albino, U. B. and Hungria, M. (2000). Importance of molybdenum and cobalt to the biological nitrogen fixation. In: F.O. Pedrosa, M. Hungria, G. Yates, W.E. Newton (eds.). Nitrogen Fixation: From Molecules to Crop Productivity, pp. 597-598, Springer, Netherlands.

Dharmalingam, C., Paramasivam and Sivasubramanian, V. (1998). Seed hardening to overcome adversity. The Hindu, No. 16 (Wednesday).

Deepika, C. and Pitagi, A. (2015). Effect of Zinc and Boron on growth, seed yield and quality of Radish (Raphanus sativus L.) cv. Arka Nishanth. Curr. Agric. Res. J., 3 (1) : 85-89.

Deb, P., Das, A., Ghosh, S. K., Suresh, C. P. (2010). Improvement of seed germination and seedling growth of papaya (Carica papaya L.) through different presowing seed treatments. Acta Hort., 851 : 313-316.

Dixit, P. M. and Elamathi, S. (2007). Effect of foliar application of DAP, micronutrients and NAA on growth and yield of green gram (Vigna radiata L.). Legume Res., 30 (4) : 305-307.

Farooq, M., Wahid, A. and Kadambot, H. and Siddique M. M.(2012).Micronutrientapplication through seed treatments - a review. J. Soil Sci. and Pl. Nutrition., 12 (1) : 125-142.

Harris, D., Rashid, A., Miraj, G., Arif, M. and Yunas, M. (2008).A 'On-farm' seed priming with zinc in chickpea and wheat in Pakistan. Pl. Soil. 306 : 3-10.

Harish Babu, B. N., Kempegowda, M. L., Kalappa, V. P. and Rudra Naik, V. (2005). Comparative evaluation of different pelleting materials on seed performance of French bean and green gram. Kar. J. Agric. Sci., 18 (1) : 32-35.

ISTA. (1999). International rules for seed testing. Seed Sci. and Technol., $27: 25-30$.

Jayaraj, T. (1997). Study of the effect of plant protection chemicals on seed quality in sesame (Sesame indicum L.) Cv. KRR 2 and TMV 3. M. Sc. (Agri.) Thesis, Tamil Nadu Agric. Univ., Coimbatore (India).

Johnson, S. E., Lauren, J. G., Welch, R. M. and Duxbury, J. M. (2005). A comparison of the effects of micronutrient seed priming and soil fertilization on the mineral nutrition of chickpea (Cicer arietinum), lentil (Lens culinaris), rice (Oryza sativa)and wheat (Triticum aestivum)in Nepal. Exper. Agric. 41 : 427-448.

Kaleeswari. R. K., Rajeswari, R. and Prabhaharan. J. (2013). A handbook of soil fertility. Satish serial publishing house.

Kaur, R., Arora, S. and Thukral, A. K. (2009). Enhancing seed germination of Chlorophytyum borivilianum Sant. Et fernand. with PGRs, steroidal hormones and zinc. Res. J. Seed Sci. 2 : 32-39.

Kavitha, S. (2002). Seed hardening and pelleting for maximizing the productivity of blackgram (Vigna mungo L. Hepper). Cv. Vamban 3 under rainfed conditions. $M$. Sc. (Agri.) Thesis, Tamil Nadu Agric. Univ., Coimbatore (India).

Krishnasamy, V. (2003). Seed pelleting principles and practices. ICAR short course on seed hardening and pelleting technologies for rainfed/garden land ecosystems. Tamil Nadu Agric. Univ., Coimbatore, p. 96.

Maguire, J. D. (1962). Speed of germination aid in selection and evaluation of seedling emergence and vigour. Crop Sci., 2 : 176-177.

Marschner, H. (1995). Mineral Nutrition of Higher Plants: $2^{\text {nd }}$ edn. Academic Press, London, UK.

Masuthi, D., Vyakaranahal, B. S. and Deshpande, V. K. (2009). Influence of pelleting with micronutrient and botanical on growth, seed yield and quality of vegetable cowpea. Kar. J. Agric. Sci., 22 (4) : 898-900.

Mengel, K., Kirkby, E. A., Kosegarten, H. and Appel, T. (2001). Principles of Plant Nutrition: Kluwer Academic Publishers, Dordrecht, The Netherlands.

Ozturk, L., Yazici, M. A., Yucel, C., Torun, A., Cekic, C., Bagci, A., Ozkan, H., Braun, H. J., Sayers, Z. and Cakmak, I. (2006). Concentration and localization of zinc during seed development and germination in wheat. Physiol. Plant., 128 : 144-152.

Rahman, M. S.,Islam, M. N., Shaheb, M. R., Arafat, M. A, 
Sarker, P. C. and Sarker, M. H. (2014). Effect of seed treatment with boron and molybdenum on the yield and Seed quality of chickpea. Int. J. Expt. Agric., 4 (3) : 1-6.

Shkolnik and Abdurashitov, S. A. (1958). Influence of micro -elements on synthesis and translocation of carbohydrates. Pl. Phy.siol., USSR, 5 (5) : 393-399.

Singh, B., Natesan, S. K. A., Singh, B. K., Usha, K. (2003). Improving zinc efficiency of cereals under zinc deficiency. Curr. Sci., $88: 36-14$.

Srimathi, P., Kavitha, S. and Renugadevi, J. (2007). Influence of seed hardening and pelleting on seed yield and quality in green gram (Vigna radiata) Cv. Co-6. Ind. $J$.
Agric. Res., 41 (2) : 122-126.

Sundararaj, N., Nagaraju, S., Venkata Ramu, M. N. and Jagannath, M. R. (1972). Design and analysis of experiments, Univ. Agric. Sci., Bangalore, 148-155.

Tanaka, M. and Fujiwar, T. (2008). Physiological roles and transport mechanisms of boron: perspectives from plants. European J. Physiol., 456 : 671-677.

Umarani, R., Sashtri, G. and Srimathi, P. (2003). Seed hardening and pelleting in greengram. ICAR Short course on Seed hardening and Pelleting Technologies for Rainfed/ Garden Land Ecosystems, Tamil Nadu Agric. Univ., Coimbatore (India). pp. 186. 